\title{
Raman Spectroscopic Analysis of Oral Squamous Cell Carcinoma and Oral Dysplasia in the High-Wavenumber Region
}

Hugh Byrne

Technological University Dublin, hugh.byrne@tudublin.ie

Luis Felipe Carvalho

Universidade do Vale do Paraiba, Brazil, luisfelipecarvalho@hotmail.com

Fiona Lyng

Technological University Dublin, fiona.lyng@tudublin.ie

See next page for additional authors

Follow this and additional works at: https://arrow.tudublin.ie/biophonart

Part of the Biochemistry, Biophysics, and Structural Biology Commons, and the Physics Commons

\section{Recommended Citation}

Carvalho, L.F. et al. (2015) Raman spectroscopic analysis of oral squamous cell carcinoma and oral dysplasia in the high-wavenumber region", Proc. SPIE 9531, Biophotonics South America, 953125 (2015); doi:10.1117/12.2180996

This Article is brought to you for free and open access by the DIT Biophotonics and Imaging at ARROW@TU Dublin. It has been accepted for inclusion in Articles by an authorized administrator of ARROW@TU Dublin. For more information, please contact arrow.admin@tudublin.ie, aisling.coyne@tudublin.ie,gerard.connolly@tudublin.ie.

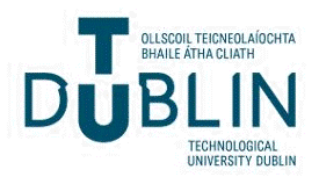




\section{Authors}

Hugh Byrne, Luis Felipe Carvalho, Fiona Lyng, and Franck Bonnier

This article is available at ARROW@TU Dublin: https://arrow.tudublin.ie/biophonart/25 


\title{
RAMAN SPECTROSCOPIC ANALYSIS OF ORAL SQUAMOUS CELL CARCINOMA AND ORAL DYSPLASIA IN THE HIGHWAVENUMBER REGION
}

\author{
LUIS FELIPE CS CARVALHO ${ }^{1,5^{*}}$, FRANCK BONNIER ${ }^{1}$, KATE O’CALLAGHAN $^{2}$, JEFF $^{\prime}$ \\ O’'SULLIVAN ${ }^{2}$, STEPHEN FLINT $^{2}$, LAZARO PM NETO ${ }^{5}$, CLÁUDIO TELLEZ ${ }^{5}$, LAURITA DOS \\ SANTOS $^{5}$, AIRTON A MARTIN ${ }^{5}$, HUGH J. BYRNE ${ }^{1}$, FIONA M. LYNG ${ }^{3,4}$ \\ ${ }^{1}$ FOCAS RESEARCH INSTITUTE, DUBLIN INSTITUTE OF TECHNOLOGY, KEVIN STREET, DUBLIN 8 \\ ${ }^{2}$ DUBLIN DENTAL SCHOOL AND HOSPITAL, TRINITY COLLEGE DUBLIN, DUBLIN 2 \\ ${ }^{3}$ RADIATION AND ENVIRONMENTAL SCIENCE CENTRE, FOCAS RESEARCH INSTITUTE, DUBLIN INSTITUTE OF TECHNOLOGY, \\ KEVIN STREET, DUBLIN 8 \\ ${ }^{4}$ SCHOOL OF PHYSICS, DUBLIN INSTITUTE OF TECHNOLOGY, KEVIN STREET, DUBLIN 8 IRELAND \\ 5 LABORATORY OF BIOMEDICAL VIBRATIONAL SPECTROSCOPY, UNIVERSIDADE DO VALE DO PARAÍBA, SÃO JOSÉ DOS \\ CAMPOS-SP BRAZIL \\ EMAIL OF CORRESPONDING AUTHOR: LUISFELIPECARVALHO@HOTMAIL.COM
}

\begin{abstract}
Raman spectroscopy can provide a molecular-level signature of the biochemical composition and structure of cells with excellent spatial resolution and could be useful to monitor changes in composition for early stage and non-invasive cancer diagnosis, both ex-vivo and in vivo. In particular, the fingerprint spectral region $\left(400-1,800 \mathrm{~cm}^{-1}\right)$ has been shown to be very promising for optical biopsy purposes. However, limitations to discrimination of dysplastic and inflammatory processes based on the fingerprint region still persist. In addition, the Raman spectral signal of dysplastic cells is one important source of misdiagnosis of normal versus pathological tissues. The high wavenumber region $\left(2,800-3,600 \mathrm{~cm}^{-}\right.$ $\left.{ }^{1}\right)$ provides more specific information based on $\mathrm{N}-\mathrm{H}, \mathrm{O}-\mathrm{H}$ and $\mathrm{C}-\mathrm{H}$ vibrations and can be used to identify the subtle changes which could be important for discrimination of samples. In this study, we demonstrate the potential of the highwavenumber spectral region by collecting Raman spectra of nucleoli, nucleus and cytoplasm from oral epithelial cancer (SCC-4) and dysplastic (DOK) cell lines and from normal oral epithelial primary cells, in vitro, which were then analyzed by area under the curve as a method to discriminate the spectra. In this region, we will show the discriminatory potential of the $\mathrm{CH}$ vibrational modes of nucleic acids, proteins and lipids. This technique demonstrated more efficient discrimination than the fingerprint region when we compared the cell cultures.
\end{abstract}

Keywords: Raman spectroscopy, high-wavenumber, optical biopsy, oral cancer

\section{INTRODUCTION}

Recently, a range of new diagnosis tools based on photonic technologies has been developed. One of these tools is the optical or spectroscopic biopsy. Optical biopsy refers to techniques where the light-tissue interaction is analyzed and information concerning the state of the tissue is obtained either "in vivo"' or "ex vivo"'. Optical spectroscopy techniques such as infrared absorption, fluorescence, and Raman scattering can be employed. Holmstrup et al. 2007 [1] described many molecular interaction features in cells and tissues that cannot be accessed by conventional histopathology that can be probed by optical techniques.

Usually, the spectral region between 500 and $1,800 \mathrm{~cm}^{-1}$ (fingerprint region) contains the most relevant biochemical information concerning biological tissues [Carvalho, Lyng, Bonnier, Nawaz, 2-6]. Many of vibrational band frequencies of amino acids, nucleic acids, proteins, lipids, glucose, and other carbohydrates fall in this region, providing a complex fingerprint of the biochemical composition, usually requiring multivariate analysis [nothinger, movasaghi7-8]. One interesting possibility is to use the so-called high wavenumber region, 2,800-3,600 cm $\mathrm{cm}^{-1}$, as it can provide more specific information based on $\mathrm{N}-\mathrm{H}, \mathrm{O}-\mathrm{H}$ and $\mathrm{C}-\mathrm{H}$ vibrations of lipids and proteins, which could be complement analysis of the fingerprint region [Carvalho 2011. 
In this study, we demonstrate the potential of the high-wavenumber spectral region by collecting Raman spectra of nucleoli, nucleus and cytoplasm from oral epithelial cancer (SCC-4) and dysplastic (DOK) cell lines and from normal oral epithelial primary cells, in vitro, which were then analyzed by area under the curve as a statistical method to discriminate the spectra. In this region we will show the discrimination comparing the $\mathrm{CH}$ vibrational modes of nucleic acids, proteins and lipids.

\section{MATERIALS AND METHODS}

\subsection{ORAL CELL LINES}

To determine the efficacy of Raman Spectroscopy in distinguishing between the cellular states observed during carcinogenic transformation, three different types of oral cell lines: SCC-4 (malignant cell line), DOK (dysplastic cell line) and Primary cells (normal oral epithelial cell line) were utilised. It is important to note that both pathological cell lines were originally from tongue, one of the sites of highest incidence of oral squamous cell carcinoma.

\subsubsection{SCC-4 and DOK cell cultures.}

The SCC-4 and DOK (HPA cultures, UK) cell lines were cultured in Dulbecco Modified Eagle's Medium (DMEM) supplemented with $10 \%$ (v/v) FBS, penicillin/streptomycin (100U/100ug) and L-glutamine (2mM). For the DOK cell line, hydrocortisone $(5 \mathrm{ug} / \mathrm{ml})$ was also added. The medium was pre-warmed at $37^{\circ} \mathrm{C}$ before incubation of the cells. Cells were cultured until $90 \%$ confluency in a humidified environment at 5\% $\mathrm{CO} 2$, before being passaged. When confluent, the cells were washed in pre-warmed phosphate buffered saline (PBS) (0.01M phosphate buffer, $0.154 \mathrm{M}$ sodium chloride) and incubated with trypsin-EDTA ( $0.5 \%$ trypsin, $0.02 \%$ EDTA) for 5 min at $37^{\circ} \mathrm{C}$. Fresh, pre-warmed medium was added to deactivate trypsin, and the suspended cells were centrifuged at $250 \mathrm{~g}$ for $5 \mathrm{~min}$. The supernatant was discarded and the cell pellet was resuspended in a sufficient volume of fresh pre-warmed medium, counted and passaged at a ratio of 1:3.

\subsubsection{Primary cell culture}

Human oral mucosa was recovered at the Dublin Dental University Hospital from patients undergoing routine third molar extraction in the Department of Oral and Maxillofacial Surgery. The sample was immediately placed into prewarmed collection medium [DMEM, penicillin/streptomycin $(100 \mathrm{U} / 100 \mu \mathrm{g})$, amphotericin B $(2.5 \mu \mathrm{g} / \mathrm{ml})$ ] for $10 \mathrm{~min}$ before washing the tissue three times with pre-warmed $1 \mathrm{X}$ PBS and placing it in $0.17 \%$ trypsin overnight at $4^{\circ} \mathrm{C}$. The following day, the sample was washed with $1 \mathrm{X}$ PBS and connective tissue was removed using a scalpel. The tissue was cut into small pieces $(1 \mathrm{~mm} \times 2 \mathrm{~mm})$ and the small sections were placed in pre-treated T25 flasks (CELL+, Sarstedt), each with a small coating of keratinocyte growth medium (KGM). These were left to adhere to the flask for $1-2 \mathrm{~h}$ and the flask was subsequently flooded with KGM. Once sufficient growth of cells from tissue was achieved (2-3 weeks), KGM was replaced with Epilife medium (Invitrogen) to select for epithelial cell growth. Cells were passaged using $0.05 \%$ trypsin and spun at $250 \mathrm{~g}$ for $10 \mathrm{~min}$ at $4^{\circ} \mathrm{C}$ and cultured to $90 \%$ confluency.

\subsubsection{Sample preparation}

To facilitate Raman spectroscopy measurements, cells were detached from the flasks using 0.025\% Trypsin-EDTA at $37^{\circ} \mathrm{C}$ and pelleted at $250 \mathrm{~g}$ for $5 \mathrm{~min}$ at room temperature. The supernatant was removed and cells were counted and seeded at a density of $5 \times 104$ cells/calcium fluoride (CaF2) disc in a multiwell plate and maintained, as previously described, until a monolayer of cells was stably growing on the disc. The cells were then fixed with $10 \%$ neutral buffered formaldehyde for $5 \mathrm{~min}$, washed with $1 \mathrm{X}$ PBS and stored in $0.9 \%$ physiological saline solution prior to capture of the Raman spectrum.

\subsection{RAMAN SPECTROSCOPY MEASUREMENTS}


The study was conducted with a Horiba Jobin-Yvon LabRam HR800 instrument using a $532 \mathrm{~nm}$ laser as the source in a backscattering geometry, and a 300 lines $/ \mathrm{mm}$ grating, providing a dispersion of $\sim 1.5 \mathrm{~cm}-1$ per pixel. The laser power was approximately $35 \mathrm{~mW}$ at the sample. Spectra were taken in the range from 2600 to $3800 \mathrm{~cm}^{-1}$ with a confocal hole diameter of $100 \mu \mathrm{m}$. A 100x water immersion objective (LUMPlanF1, Olympus, N.A.: 1.0) was used to focus the laser on the sample, immersed in distilled water, providing a spatial resolution of $\sim 1 \mu \mathrm{m}$ (Fullwood et al., 2014; Bonnier et al., 2012 and Bonnier et al., 2010). Water immersion has been demonstrated to reduce any photothermal damage to the cells during measurement, and the signals were observed to be stable and reproducible (Bonnier et al., 2012). For each cell line, 20 cells were analyzed. For each cell, three different subcellular regions were analyzed, resulting in one spectrum for each subcellular region of each cell. Thus, for each cell line, 20 nucleolar, 20 nuclear and 20 cytoplasmic spectra were recorded, each for a period of 2 x 20 seconds (Figure1).

\subsection{DATA PREPROCESSING}

Data preprocessing was performed using a LabSpec. Before statistical analysis, a Savitsky-Golay filter (5th order, 7 points) was applied to smooth the spectra. As it has been demonstrated that, in water immersion, the background to the Raman spectrum is simply the spectrum of the overlying water (Bonnier et al., 2011), no background was subtracted. All spectra were (vector) normalized to remove point to point intensity variations and facilitate comparison of all spectra.

\subsection{DATA ANALYSIS}

The data analysis were performed using the values of integrated area under the curve from $2829 \mathrm{~cm}^{-1}-3023 \mathrm{~cm}^{-1}$ region for all Raman spectra. This region comprises mainly the vibrational modes of $\mathrm{CH}_{3}$ and $\mathrm{CH}_{2}$ assymetric stretching which is related to structural components of nucleic acids, lipids and proteins.

An intergroup statistical comparison of the $2829 \mathrm{~cm}^{-1}-3023 \mathrm{~cm}^{-1}$ region of Raman spectra for cytoplasm, nucleus and nucleolus was carried out using the unpaired Student's $t$ test, with $p<0.05$ considered as a significant difference and $p<$ 0.0001 considered as a very significant difference. The Mann-Whithney test was used as an equivalent approach to the Student's $t$ test when the data did not follow a Gaussian distribution.

\section{RESULTS AND DISCUSSION}

\subsection{SINGLE CELL ANALYSIS}

Analysis of the subcellular regions, nucleolus, nucleus and cytoplasm, from the primary cell culture (Figure 1 A), was completed and the different subcellular regions were compared. Figure 1 (B, C, D) shows the average spectra for each subcellular region, the standard deviation being illustrated by the shaded region. All spectra have been normalized to 1 at the maximum of the water bands. In all spectra, the region from $\sim 3100-3400 \mathrm{~cm}^{-1}$ is dominated by the features of water, and thus was not included in the spectral analysis. Visually, it is possible to note the similarities, and few differences between the average spectra of the nucleolus and nucleus are apparent. That of the cytoplasm is, however, clearly different in the region between $2800-3000 \mathrm{~cm}^{-1}$. These features can be associated with specific chemical compounds as indicated in Table 1, and their differing relative strengths are an indication of differing chemical composition of the subcellular region analysed. For example, the peak at $2851 \mathrm{~cm}^{-1}$ can be associated with $\mathrm{CH}_{2}$ stretching in lipidic components, fatty acids and phospolipids, which are relatively strong in the cytoplasm, while the peak at $2940 \mathrm{~cm}^{-1}$ is associated with $\mathrm{CH}$ vibrational modes of nucleic acids, predictably relatively strong in the nucleus and nucleolus. (Carvalho et al., 2011; Movasaghi et al., 2007).

In the comparison of the three subcellular regions, by visual inspection, the spectra of the nucleus and nucleolus can clearly be differentiated from that of cytoplasm. The biochemical composition of the cytoplasm is significantly different from that of the nucleus and nucleoli. However, the two nuclear regions are not as different, and multivariate analysis is required to differentiate the spectra from the different regions (ref Carvahlo). 


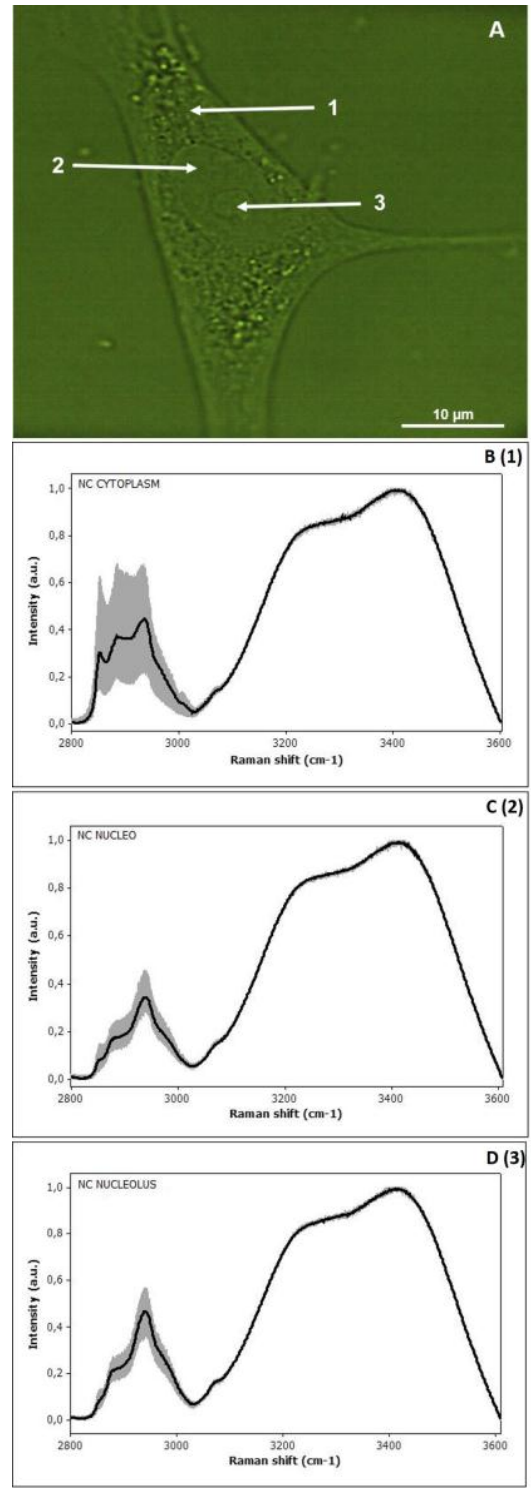

Figure 1. A - Optical Micrograph of a primary cell cultured from human mucoperiosteal tissue. Mean Raman spectra from (B) Cytoplasm (C) Nucleus (D) Nucleolus of normal cell line with the standard deviation denoted by the shaded region.

\subsection{SQUAMOUS CELL CARCINOMA vS DYSPLASTIC CELLS vs NORMAL CELLS}

In individual cell lines, Raman spectroscopy has thus been demonstrated to be a powerful tool to discriminate different subcellular regions based on their biochemical content. The technique has previously been extended to differentiate between different cell lines, representing different oral pathologies in the fingerprint region $\left(400-1800 \mathrm{~cm}^{-1}\right)(\mathrm{Carvalho}$ et al., 2015), warranting a comparison of the differentiating capability of the high wavenumber region.

The spectra of the three subcellular regions of the three cell-lines in the high wavenumber region are shown in Figure 2. After statistical analysis, in order to discriminate the samples, it was seen that, in almost every comparison, discrimination could be achieved using the integrated area $\left(2800-3020 \mathrm{~cm}^{-1}\right)$. The only comparison which was not statistical relevant $(p>0.05)$ was that of cancer cells with normal cells in the cytoplasmic region (Figure 3 ). In contrast, the comparison between cancer, pre cancer and normal cells in the nucleus and nucleolus was very good, as in these subcellular regions all cells cultures were discriminated with $p<0.0001$. 

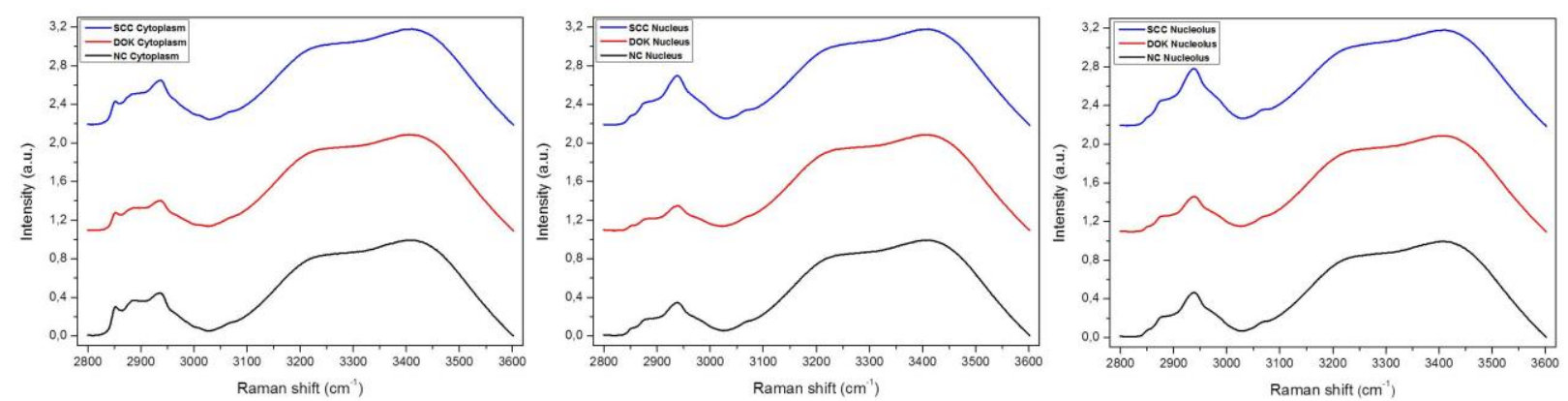

Figure 2 Mean spectra of the three cell cultures in the subcellular regions analyzed, normalized to one and off set for clarity. From right to left - Nucleolus - Nucleus - Cytoplasm, and SCC in blue, DOK in red and Normal in black.

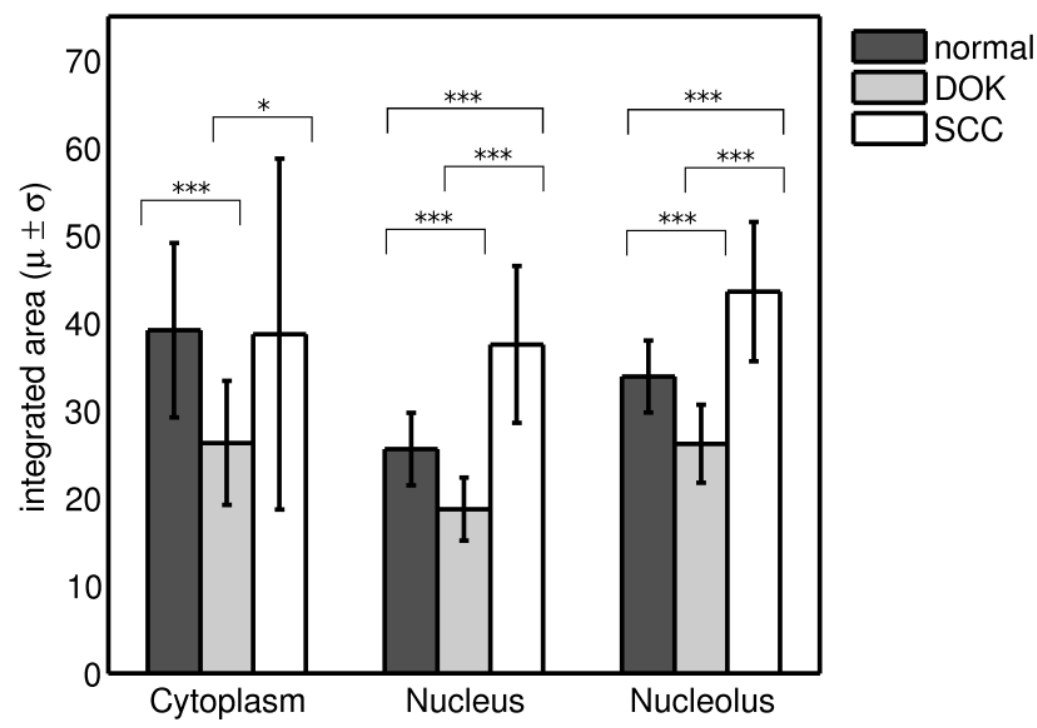

Figure 3 Comparison between the three cell lines and respective subcellular regions. The asterisk * showed the relevance of test, as one $*$ is related to $p<0.05$ considered as significant difference and three $* p<0.0001$ considered as very significant difference.

Table 1: Raman spectroscopic band assignments (ref)

\begin{tabular}{lcl}
\hline & Peak $\left(\mathbf{c m}^{-1}\right)$ & \multicolumn{1}{c}{ Assignment } \\
\hline Cytoplasm & 2884 & $v_{\mathrm{s}} \mathrm{CH}_{3}$, lipids, fatty acids \\
& 2938 & $\mathrm{C}-\mathrm{H}$ vibrations in lipids \& proteins, vas $\mathrm{CH}_{2}$, lipids, fatty acids \\
Nucleus & 2852 & $\mathrm{CH}_{2}$ symmetric stretch of lipids \& $\mathrm{CH}_{2}$ asymmetric stretch of lipids and \\
& 2938 & proteins \\
& 2852 & $\mathrm{C}-\mathrm{H}$ vibrations in lipids \& proteins, $\mathrm{v}_{\mathrm{as}} \mathrm{CH}_{2}$, lipids, fatty acids \\
Nucleolus & 2938 & proteins \\
& & C-H vibrations in lipids \& proteins, vas $\mathrm{CH}_{2}$, lipids, fatty acids \\
\hline
\end{tabular}




\subsubsection{Nucleolus and Nucleus}

The plot of Figure 2D shows the average spectral data of the nucleolus of normal cells (black) abnormal cells (SCC-4 (blue) and DOK (red). In this region, the ribosomal RNAs that form ribosomes are transcribed, which are essential structures for protein synthesis. As the rate of formation of such RNA is rapid, it accumulates in the nucleus and forms a dense mass, the nucleolus. Nucleoli are organoid structure present in eukaryotic cells, particularly responsible for coordinating the reproductive process of the cells (although they soon disappear at the beginning of cell division) and the control of basic cellular processes, as they contain specific DNA sections, in addition to numerous associated proteins.

Figure 2C shows the average spectra of nucleus. The cell nucleus is a structure surrounded by membrane that protects the DNA in eukaryotic cells (from fungi to plants and animals). The membrane is called the nuclear membrane and is very similar in composition to the plasma membrane, a double lipoprotein layer. It has numerous pores which permit communication with the cytoplasm and the flow of various substances, such as RNA. In most of our cells, there is only one core, and spherical center position, but there are cells that lack nuclei (eg red blood cells) and cells with more than one core (eg, muscle cells). The matrix within the nucleus is the nucleoplasm, which is similar to the cytoplasm and forms a protein gel where all structures are located. It is in the core that chromosomes are contained, which control the operation of the cell, and this is where the replication and transcription processes occur [12,13]. The primary function of the nucleus, therefore, is to protect the DNA. This could be the reason why that the vibrational modes of proteins, such as that at $2940 \mathrm{~cm}^{-1}$, are observed with high intensity in the nucleolus and nucleus spectra.

\subsubsection{Cytoplasm}

Figure 2B shows the average spectra of the cytoplasmic regions of each of the three cell lines. The cytoplasm is the intracellular space between the plasma membrane and the nuclear envelope in eukaryotic beings, whereas in prokaryotes it corresponds to the entire intra-cellular area. The cytoplasm is filled with a colloidal matter and semi-fluid called cytosol, and cell organelles are suspended in this fluid. The movement of calcium ions into and out of the cytoplasm is considered to be a signaling activity of metabolic processes. The cytosol is the portion not contained within the cytoplasmic membrane. The cytosol occupies about $70 \%$ of the cell volume and is composed of water, salts and organic molecules. The cytosol is a complex mixture of cytoskeleton filaments dissolved molecules and water that fills most of the volume of a cell. The cytosol protein also contains filaments that form the cytoskeleton and dissolved protein and small structures such as ribosomes, complex proteasome $[12,13]$.

As the cytoplasm has a more diverse biochemical makeup, as many structural organelles and chemical reactions occur in this subcellular region, the variability of the spectra is higher than that of the nucleus and nucleolus. Also, many lipids, phospolipds and fatty acids are found in the cytoplasm, which is reflected in the vibrational modes of $\mathrm{CH}_{2}$ stretching in $2851 \mathrm{~cm}^{-1}$.

After completion of the statistical tests, significant differences were observed between the three groups of cells (SCC, DOK and Normal), as shown in Figure 3 mainly in the regions of the nucleus and nucleolus. As previously mentioned, the massive structure of these subcellular regions is mostly composed of nucleic acids such as DNA. In the process of carcinogenesis, the tissue changes begin as a single cell change, which occurs mainly at nucleolar level, with change in the genetic material (DNA), so we can show that Raman spectroscopy was effective to distinguish the cell groups through the data on area under the curve.

\section{FINAL REMARKS}

In conclusion, the results of the present work demonstrate the capacity of the high-wavenumber region $\left(2,800-3,600 \mathrm{~cm}^{-}\right.$ $\left.{ }^{1}\right)$ to discriminate between the three subcellular regions (cytoplasm, nucleus and nucleoli). Significantly, it was also possible to discriminate the cell cultures by directly probing the integrated area of 2,800-3,000 $\mathrm{cm}^{-1}\left(\mathrm{CH}_{2}\right.$ and $\mathrm{CH}_{3}$ stretch vibrations). The discriminative power is obtained applying Mann-Whitney test or T-student test in the integrated 
area values. Moreover, detailed studies need be performed to discriminate each contribution to the spectra and molecular complex. Deconvolution of the spectra will be very useful to match the relate bands and vibrational modes with their experimental results.

\section{ACKNOWLEDGMENTS}

Luis Felipe CS Carvalho was funded in part by the Conselho Nacional de Desenvolvimento Científico e Tecnológico (CNPq - 237749/2012-2)) and by Fundação de Amparo à Pesquisa do Estado de São Paulo (FAPESP - 2014/05978-1). Laurita dos Santos was support by CAPES 88881062862/2014-01. This research was supported in part by the science foundation Ireland (12/ip/1494) and the National Biophotonics and Imaging Platform Ireland (NBIPI), funded under the Higher Education Authority PRTLI (Programme for Research in Third Level Institutions) Cycle 4, Co-funded by the Irish Government and the European Union Structural Fund.

\section{REFERENCES}

[1] Bonnier F, Ali SM, Knief P, Lambkin H, Flynn K, McDonagh V, et al. (2012). Analysis of human skin tissue by Raman microspectroscopy: Dealing with the background. Vibrat Spec 61:124-132.

[2] Bonnier F, Mehmood A, Knief P, Meade AD, Hornebeck W, Lambkin H, et al. (2010). In vitro analysis of immersed human tissues by Raman microspectroscopy. J Ram Spec 42(5):888 - 896.

[3] Byrne HJ, Ostrowska KM, Nawaz H, Dorney J, Meade AD, Bonnier F, et al. (2014). Vibrational Spectroscopy: Disease Diagnostics and Beyond, in Optical Spectroscopy and Computational Methods in Biology and Medicine, Challenges and Advances in Computational Chemistry and Physics, 14: 355-99.

[4] Carvalho LF, Bitar RA, Arisawa EA, Brandão AA, Honório KM, Cabral LA, et al (2010). Spectral region optimization for Raman-based optical biopsy of inflammatory lesions. Photomed Laser Surg 28 Suppl 1:S111-7.

[5] Evers D, Hendriks B, Lucassen G, Ruers T (2012). Optical spectroscopy: current advances and future applications in cancer diagnostics and therapy. Future Oncol 8(3):307-20.

[6] Guze K, Short M, Zeng H, Lerman M, Sonis S (2011). Comparison of molecular images as defined by Raman spectra between normal mucosa and squamous cell carcinoma in the oral cavity. J Raman Spectrosc 42(6):12321239.

[7] Kallaway C, Almond LM, Barr H, Wood J, Hutchings J, Kendall C, et al. (2013). Advances in the clinical application of Raman spectroscopy for cancer diagnostics. Phot Photodyn Ther 10(3):207-19.

[8] Kelly K, Johnson-Obaseki S, Lumingu J, Corsten M (2014). Oncologic, functional and surgical outcomes of primary transoral robotic surgery for early squamous cell cancer of the oropharynx: a systematic review. Oral Oncol S13688375(14)00128-6.

[9] Kelly JG, Trevisan J, Scott AD, Carmichael PL, Pollock HM, Martin-Hirsch PL, et al. (2011). Biospectroscopy to metabolically profile biomolecular structure: a multistage approach linking computational analysis with biomarkers. J Proteome Res 10(4):1437-48.

[10] Lasalvia M, D'Antonio P, Perna G, Capozzi V, Mariggiò MA, Perrone D, et al (2015). Discrimination of different degrees of oral squamous cell carcinoma by means of Raman microspectroscopy and atomic force microscopy. Anal Methods 7:699-707.

[11]Lyng FM, Faoláin EO, Conroy J, Meade AD, Knief P, Duffy B, et al. (2007). Vibrational spectroscopy for cervical cancer pathology, from biochemical analysis to diagnostic tool. Exp Mol Pathol 82(2):121-9.

[12] Nawaz H, Bonnier F, Meade AD, Lyng FM, Byrne HJ (2011). Comparison of subcellular responses for the evaluation and prediction of the chemotherapeutic response to cisplatin in lung adenocarcinoma using Raman spectroscopy. Analyst 136(12):2450-63.

[13] Notingher I (2007). Raman biospectroscopy cell based biosensors. Sensors 7:1343-1358.

[14] Peer D (2014). Precision medicine - Delivering the goods? Cancer Lett S0304-3835(14)00218-3.

[15] Schubert JA, Bird B, Papamarkakis K, Miljković M, Bedrossian K, Laver N, et al (2010). Spectral cytopathology of cervical samples: detecting cellular abnormalities in cytologically normal cells. Lab Invest 90(7):1068-1077.

[16] Raman CV, Krishnan KS (1928). A new type of secondary radiation. Nature 121: 501-502. 